\title{
Penandaan Alfa-Mangostin dengan Radionuklida Teknesium-99m sebagai Senyawa Deteksi Kanker
}

\section{Luthfi Utami Setyawati1, ${ }^{*}$, Risda Rahmi Islamiaty ${ }^{1}$, Kevin Reinard Lie ${ }^{1}$, Cindy Aprillianie Wijaya ${ }^{1}$, Muchtaridi Muchtaridi²}

\author{
${ }^{1}$ Program Studi Sarjana Farmasi, Fakultas Farmasi, Universitas Padjadjaran \\ 2Departemen Analisis Farmasi dan Kimia Medisinal, Fakultas Farmasi, Universitas Padjadjaran \\ *email: luthfi.utamis@gmail.com \\ (Submit 15/8/2019, Diterima 21/8/2019)
}

\begin{abstract}
Abstrak
a-mangostin merupakan turunan xanthon yang banyak terdapat pada kulit dan buah manggis. a-mangostin memiliki kemampuan menekan pembentukan senyawa karsinogen yang merupakan salah satu penyebab terjadinya kanker. a-mangostin dapat membentuk kompleks khelat dengan logam seperti teknesium-99m (99mTc), sehingga dapat membentuk sediaan radiofarmaka yang dapat digunakan sebagai diagnosis kanker. Penelitian ini bertujuan untuk mendapatkan sediaan radiofarmasi 99mTcAlfamangostin dengan metode langsung dengan melakukan optimalisasi terhadap beberapa parameter seperti jumlah reduktor, kondisi $\mathrm{pH}$, jumlah ligan, dan waktu inkubasi. Penentuan kemurnian radiokimia dilakukan dengan kromatografi lapis tipis dengan pengembang campuran amonia : etanol : air dengan perbandingan $1: 2: 5$ untuk memisahkan pengotor radiokimia berupa TcO2 dan $\mathrm{NaCl} 0,9 \%$ untuk memisahkan pengotor radiokimia berupa $\mathrm{TcO} 4$. Kondisi optimum penandaan diperoleh pada $\mathrm{pH} 9$, dengan jumlah reduktor $50 \mu \mathrm{l}$, jumlah ligan $\alpha$-mangostin $1000 \mu \mathrm{g}$ dengan waktu penandaan pada menit ke 0 pada suhu kamar (250C) dengan kemurnian radiokimia $86.5 \pm 1,31 \%$.
\end{abstract}

Kata kunci : Kanker, a-mangostin, Teknesium-99m, Radiofarmaka

\section{Outline}

- Pendahuluan

- Metode

- Hasil dan Pembahasan

- Kesimpulan

- Ucapan Terima Kasih

- Daftar Pustaka

\section{Pendahuluan}

Buah manggis merupakan buah yang telah banyak digunakan dalam pengobatan Cina dan Ayurvedic. Buah ini mengandung banyak vitamin dan mineral, termasuk vitamin $C$, fosfor, besi, riboflavin (B12), dan niasin (B3). Buah manggis juga telah ditemukan mengandung zat-zat yang memiliki efek antihistamin, kemoprotektif, dan kelas senyawa polifenol alami yang disebut xanthon (1). 
Sebanyak 50 xanthon telah diisolasi dari kulit buah manggis. Xanthon atau adalah metabolit sekunder yang ditemukan pada beberapa keluarga tanaman, termasuk jamur dan lumut. Dari semua turunan xanthon, $\alpha$-mangostin telah menunjukkan aktivitas antikanker terbesar pada kanker prostat, payudara, paru-paru, dan kolorektal. Senyawa ini dapat diisolasi dari kulit buah manggis dan memiliki rumus molekul $\mathrm{C}_{24} \mathrm{H}_{22} \mathrm{O}_{6}$ (2).

Sejak penemuan a-mangostin pada tahun 1855 oleh W.Schmid dari kulit buah manggis (Garcinia mangostana Linn), telah banyak studi yang dilakukan pada senyawa ini baik pada isolasi, struktural dan juga sifat biologisnya (3). Diantara banyak studi yang dilakukan, sifat antikanker dan sitotoksik dari a-mangostin telah dipelajari melalui sejumlah studi. Berdasarkan penelitian Matsumoto et al. (2003), a-mangostin pada konsentrasi $10 \mu \mathrm{M}$ menunjukkan inhibisi sempurna pada sel line leukimia HL60 pada manusia melalui induksi apoptosis (4).

Melanjutkan temuan di atas, Nabandith et al. (2004) melakukan penelitian in vivo aktivitas kemopreventif a-mangostin pada lesi preneoplastik putatif yang terlibat pada karsinogenesis kolon tikus, yang diinduksi 1,2-dimetilhidrazin (DMH). Pemberian senyawa tersebut selama 4-5 minggu, menghambat induksi dan perkembangan aberrant crypt foci (ACF), menurunkan dysplastic foci (DF) dan betacatenin accumulated crypts (BCAC). a-mangostin menurunkan terjadinya lesi focal dan epitelium kolon tikus pada pelabelan antigen nukleus sel yang mengalami proliferasi (5). Pada saat yang sama, penelitian Sato et al. (2004) menunjukkan a-mangostin menginduksi Ca2+-ATPase-dependent apoptosis melalui jalur mitokondria pada sel PC12. Penelitian lain menunjukkan nilai IC50 dari a-mangostin hampir sama dengan 5FU pada model sel DLD-1 SLJJ-1 (6). a-mangostin juga memiliki potensi kemopreventif atau agen antikanker dengan hasil signifikan berupa pengurangan in vivo dari metastasis kelenjar getah bening (7). Selain penelitian tersebut, masih banyak penelitian yang menunjukkan sifat antikanker dan sitotoksik dari $\alpha-m a n g o s t i n$.

Berdasarkan sifat antikanker dan sitotoksiknya, penandaan a-mangostin dengan radionuklida teknesium-99m dapat digunakan sebagai salah satu senyawa kit diagnostik dini kanker baru. Penggunaan senyawa bertanda, senyawa yang ditandai dengan isotop radioaktif (radioisotop) tertentu, berkembang dengan pesatnya. Sebagian besar dari senyawa bertanda telah digunakan dalam bidang kedokteran. 95\% dari senyawa bertanda digunakan untuk tujuan diagnosis (8).

Berbagai senyawa bertanda, misalnya ${ }^{99 m} T e k n e s i u m ~\left({ }^{99 m} \mathrm{Tc}\right)$-sestamibi telah digunakan untuk deteksi dini kanker payudara. Akan tetapi senyawa tersebut mempunyai risiko besar yaitu dapat menyebabkan kanker sehingga tidak sesuai untuk pemeriksaan kanker payudara secara umum pada pasien (9). ${ }^{99 \mathrm{~m} T e k n e s i u m ~}\left({ }^{99 \mathrm{~m} T c)}\right.$-medronate juga telah digunakan untuk diagnosis kanker tulang namun memiliki spesifisitas dan sensitivitas yang rendah (10). Selain senyawa tersebut, ${ }^{99 m}$ Teknesium $\left({ }^{99 m} \mathrm{Tc}\right)$ -

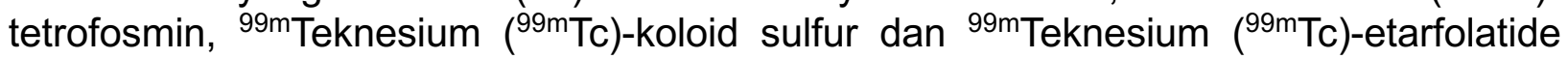
juga masih menunjukkan efek samping seperti gangguan hati dan otak meskipun memiliki spesifisitas yang lebih baik (11). Maka, untuk mengatasi masalah ini masih diperlukan radiofarmaka alternatif sehingga diagnosis dini kanker dapat dilakukan. 
Radiofarmaka merupakan suatu senyawa yang mengandung radioaktif dan digunakan baik untuk tujuan diagnosis maupun terapi. Perbedaan utama dari radiofarmaka untuk tujuan diagnosis dan terapi adalah berdasarkan radionuklida yang digunakan. Radionuklida pemancar gamma yang sering digunakan untuk tujuan diagnosis diantaranya adalah teknesium- ${ }^{99 m}$ ( $\left.{ }^{99 m} \mathrm{Tc}\right)$, karena memancarkan gamma murni dengan waktu paruh 6 jam dan energi $140 \mathrm{keV}$. Teknesium dapat berikatan dengan senyawa yang memiliki gugus donor elektron di dalam molekulnya seperti $\alpha$-mangostin, baik secara langsung ataupun tidak langsung (12).

Penandaan $\alpha$-mangostin dengan teknesium-99m $\left.{ }^{99 m} \mathrm{Tc}\right)$ diharapkan menghasilkan senyawa bertanda yang dapat digunakan sebagai kit diagnostik dini baru untuk penyakit kanker. Untuk mendapatkan kondisi penandaan yang optimal dengan hasil yang maksimal, maka dilakukan variasi beberapa parameter, antara lain, tingkat keasaman $(\mathrm{pH})$, jumlah reduktor, jumlah ligan a-mangostin, dan waktu inkubasi.

\section{Metode}

Penyiapan Larutan $\mathrm{SnCl}_{2}$, a-mangostin, dan $\mathrm{Na}^{99 m} \mathrm{TcO}_{4}$

Larutan $\mathrm{SnCl} 2$ dibuat dengan menambahkan sebanyak $5 \mathrm{mg} \mathrm{SnCl} 2 \cdot 2 \mathrm{H}_{2} \mathrm{O}$ kedalam vial berisi $5 \mathrm{~mL} \mathrm{HCl} \mathrm{0,1} \mathrm{N}$. Vial yang berisi larutan $\mathrm{SnCl} 2$ kemudian divakum dan disimpan pada suhu ruang. Larutan harus dibuat dalam keadaan segar. Larutan a-mangostin

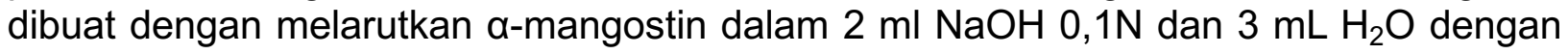
konsentrasi $5 \mathrm{mg} / 5 \mathrm{~mL}$. Larutan $\mathrm{Na}^{99 \mathrm{~m}} \mathrm{TcO}_{4}$ disiapkan dari generator $99 \mathrm{Mo} / 99 \mathrm{mTc}$ kemudian diukur radioaktivitasnya menggunakan dose calibrator.

\section{Penentuan tingkat keasaman $(\mathrm{pH})$ optimum}

Penentuan $\mathrm{pH}$ optimum sediaan dilakukan dengan memvariasikan $\mathrm{pH}$ larutan sebelum dilakukan penandaan. Kedalam 6 vial yang masing-masing berisi $500 \mu \mathrm{l}$ larutan $\alpha$ mangostin $(1 \mathrm{mg} / \mathrm{mL})$ ditambahkan larutan $\mathrm{SnCl}_{2}$ dengan volume $50 \mu \mathrm{l}$. Tingkat keasaman larutan pada setiap vial divariasikan pada $\mathrm{pH} 5,6,7,6$, 8, dan 9 dengan menambahkan tetes demi tetes $\mathrm{HCl} \mathrm{0,1} \mathrm{N}$. Volume pada setiap vial disamakan dengan penambahan $\mathrm{NaCl}$. Kedalam masing-masing vial ditambahkan $300 \mu l \mathrm{Na99mTcO} 4$ dengan aktivitas $\pm 1 \mathrm{mCi}$ dalam $\mathrm{NaCl}$ fisiologis sehingga volume akhir sama dengan 1 $\mathrm{mL}$. Kondisi $\mathrm{pH}$ setelah penambahan $\mathrm{Na}^{99 \mathrm{~m}} \mathrm{TcO}_{4}$ diperiksa dengan kertas $\mathrm{pH}$ indikator dan tidak diatur kembali. Selanjutnya larutan diinkubasi selama 30 menit pada temperatur ruang. Kemurnian radiokimia ditentukan dengan metode kromatografi.

\section{Penentuan jumlah optimum reduktor $\mathrm{SnCl}_{2}$}

Penentuan jumlah optimum reduktor $\mathrm{SnCl} 2.2 \mathrm{H} 2 \mathrm{O}$ dilakukan dengan memvariasikan larutan $\mathrm{SnCl}$. Kedalam empat vial yang masing-masing berisi $500 \mu \mathrm{l}$ larutan $\alpha-$ mangostin $(1 \mathrm{mg} / \mathrm{mL})$ ditambahkan larutan $\mathrm{SnCl} 2$ bervariasi masing-masing dengan volume $25 \mu \mathrm{l}, 50 \mu \mathrm{l}, 75 \mu \mathrm{l}$, dan $100 \mu \mathrm{l}$. Larutan pada masing-masing vial diatur pada $\mathrm{pH}$ optimum dengan penambahan tetes demi tetes $\mathrm{HCl} 0,1 \mathrm{~N}$. 


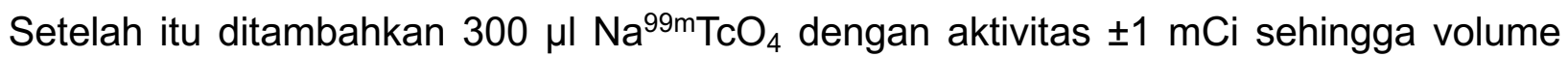
akhir sama dengan $1 \mathrm{~mL}$. Selanjutnya larutan diinkubasi selama 30 menit pada temperatur ruang. Kemurnian radiokimia ditentukan dengan metode kromatografi.

\section{Penentuan jumlah optimum ligan $\alpha$-mangostin}

Penentuan jumlah optimum ligan a-mangostin dilakukan dengan memvariasikan jumlah a-mangostin. Kedalam lima vial yang masing-masing berisi larutan $\alpha$-mangostin dalam $\mathrm{NaOH} 250 \mu \mathrm{g} / 500 \mu \mathrm{l}, 500 \mu \mathrm{g} / 500 \mu \mathrm{l}, 750 \mu \mathrm{g} / 500 \mu \mathrm{l}, 1000 \mu \mathrm{g} / 500 \mu \mathrm{l}, 1250 \mu \mathrm{g} / 500 \mu$. Selanjutnya setiap vial ditambahkan larutan $\mathrm{SnCl} 2$ dengan volume optimum. Larutan pada masing-masing vial diatur pada $\mathrm{pH}$ optimum dengan penambahan tetes demi tetes $\mathrm{HCl} 0,1 \mathrm{~N}$. Setelah itu ditambahkan $300 \mu \mathrm{l} \mathrm{Na99mTcO} 4$ dengan aktivitas $\pm 1 \mathrm{mCi}$ sehingga volume akhir sama dengan $1 \mathrm{~mL}$. Selanjutnya larutan diinkubasi selama 30 menit pada temperatur ruang. Kemurnian radiokimia ditentukan dengan metode kromatografi.

\section{Penentuan waktu inkubasi optimum}

Penentuan waktu inkubasi optimum larutan dilakukan dengan memvariasikan waktu reaksi larutan setelah ditandai Teknesium-99m. Kedalam satu buah vial yang berisi larutan a-mangostin dengan volume optimum ditambahkan larutan $\mathrm{SnCl} 2$ dengan volume optimum. Larutan pada masing-masing vial diatur pada $\mathrm{pH}$ optimum dengan penambahan tetes demi tetes $\mathrm{HCl} 0,1 \mathrm{~N}$. Setelah itu ditambahkan $300 \mu \mathrm{l} \mathrm{Na}{ }^{99 m} \mathrm{TcO}_{4}$ dengan aktivitas $\pm 1 \mathrm{mCi}$. Selanjutnya larutan diinkubasi pada temperatur ruang dan dingin dengan variasi waktu inkubasi $0,15,30,45$, dan 60 menit. Kemurnian radiokimia ditentukan dengan metode kromatografi. Hal yang sama dilakukan pada suhu inkubasi $4^{\circ} \mathrm{C}$.

\section{Penentuan kemurnian radiokimia ${ }^{99 m} T c-\alpha-m a n g o s t i n$}

Penentuan kemurnian radiokimia 99mTc-a-mangostin dilakukan dengan kromatografi lapis tipis menggunakan kertas TLC-SG F254 dan ITLC SG. Plat dengan ukuran $1 \mathrm{~cm} \mathrm{x}$ $10 \mathrm{~cm}$ diberi tanda pada tiap sentimeternya dari mulai angka $-1,0,1,2,3,4,5,6,7$, dan 8. Sebelum digunakan kertas kromatografi dipanaskan beberapa menit didalam oven untuk menghilangkan kadar air. ${ }^{99 m T c-\alpha-m a n g o s t i n ~ d i t o t o l k a n ~ p a d a ~ k e r t a s ~}$ kromatogram pada titik 0 . Pada kertas lain ditotolkan juga larutan teknesium-99m perteknektat. Setelah itu, kertas digantungkan pada pengait dan dicelupkan pada eluen. Fase diam dielusi dengan fase gerak menggunakan perbandingan amonia:air:etanol $=$

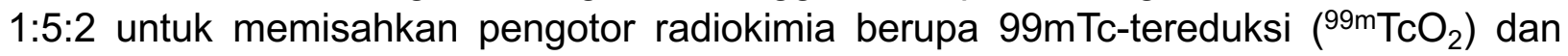
$\mathrm{NaCl} 0,9 \%$ untuk memisahkan pengotor radiokimia ${ }^{99 m} \mathrm{TcO}_{4}^{-}$. Setelah eluen mencapai angka 8, kertas kromatografi diangkat kemudian dikeringkan menggunakan oven sampai kertas mengering. Setelah kertas kering, kertas kromatogram diletakkan diatas plat alumunium kemudian diletakkan pada alat tersebut untuk dicacah. Prosedur yang sama juga dilakukan terhadap blanko. Hasil cacahan kemudian dihitung untuk mendapatkan persen pengotor berupa ${ }^{99 \mathrm{~m}} \mathrm{TcO}_{2}$ dan ${ }^{99 \mathrm{~m}} \mathrm{TcO}_{4}{ }^{-}$. 


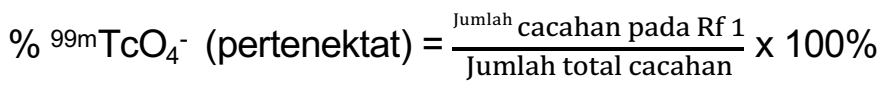

$\%{ }^{99 m} \mathrm{TcO}_{2}$ (tereduksi) $=\frac{\text { Jumlah cacahan pada Rf o }}{\text { Jumlah total cacahan }} \times 100 \%$

\% Kemurnian Radiokimia 99mTc- $\alpha$-mangostin : $100 \%-\left(\% 99 m \mathrm{TcO}_{4}^{-}+\% 99 \mathrm{~m} \mathrm{TcO}_{2}\right)$

\section{Hasil dan Pembahasan}

Derajat keasaman atau $\mathrm{pH}$ reaksi merupakan parameter penting yang perlu diperhatikan karena sangat berpengaruh terhadap kestabilan dan kelarutan senyawa ligan. Adapun rentang $\mathrm{pH}$ yang dapat diterima untuk sediaan yang akan diberikan secara intravena adalah $3-10,5$ sedangkan sediaan yang diberikan tidak secara intravena range $\mathrm{pH}$ nya adalah $3-9$ (13). Pada penelitian ini, penentuan tingkat keasaman optimum tidak dilakukan dan diambil titik 9 sebagai $\mathrm{pH}$ optimum penandaan a-mangostin dengan ${ }^{99 m}$ Teknesium. Hal ini disebabkan karena pada beberapa kali percobaan pada $\mathrm{pH}$ dibawah 9 terbentuk larutan koloid putih dan keruh. Dari hasil percobaan diperoleh data jumlah $\mathrm{SnCl}_{2} \cdot 2 \mathrm{H}_{2} \mathrm{O}$ yang diperlukan untuk mendapatkan hasil penandaan optimum adalah sebesar $50 \mu \mathrm{g}$ dengan kemurnian radiokimia $64,36 \pm 1,5 \%$ (Tabel 1). Pada jumlah $\mathrm{SnCl}_{2} \cdot 2 \mathrm{H}_{2} \mathrm{O}$ dibawah dan diatas $50 \mu \mathrm{g}$ menunjukkan hasil kemurnian radiokimia yang lebih rendah. Hal tersebut disebabkan karena Sn(II) belum cukup untuk mereduksi Tc(VII) menjadi Tc(IV). Pada jumlah $\mathrm{SnCl}_{2} \cdot 2 \mathrm{H}_{2} \mathrm{O}$ diatas $50 \mathrm{\mu g}$ juga menunjukkan hasil kemurnian radiokimia yang lebih rendah. Hal ini dikarenakan pengotor ${ }^{99 \mathrm{~m}} \mathrm{Tc}$ tereduksi $\left({ }^{99 \mathrm{~m}} \mathrm{TcO}_{2}\right)$ yang dihasilkan akan lebih banyak karena semakin banyak ${ }^{99} \mathrm{TcO}_{4}^{-}$yang tereduksi. Hal tersebut sesuai dengan reaksi reduksi perteknetat $\left(\mathrm{TcO}_{4}{ }^{-}\right)$oleh $\mathrm{SnCl}_{2}$.

Tabel 1. Hasil Penentuan Reduktor Optimum ${ }^{99 m}$ Tc-a-mangostin

\begin{tabular}{|c|c|c|c|}
\hline Jumlah & \multicolumn{3}{|c|}{ Kemurnian Radiokimia (\%) } \\
\hline $\mathrm{SnCl}_{2} \cdot 2 \mathrm{H}_{2} \mathrm{O}$ & ${ }^{99 \mathrm{~m}_{\mathrm{TcO}}}{ }_{4}^{-}$ & ${ }^{99} \mathrm{mcO}_{2}$ & ${ }^{99 m} \mathrm{Tc}-\alpha$-mangostin \\
\hline $25 \mu l$ & $36,19 \pm 1,48$ & $10,44 \pm 0,61$ & $53,38 \pm 1,61$ \\
\hline $50 \mu \mathrm{l}$ & $24,93 \pm 4,72$ & $15.39 \pm 0,81$ & $64,36 \pm 1,50$ \\
\hline $75 \mu \mathrm{l}$ & $14,38 \pm 1,35$ & $35,56 \pm 1,04$ & $49,80 \pm 1,84$ \\
\hline $100 \mu \mathrm{l}$ & $13,67 \pm 0,56$ & $39,47 \pm 0,26$ & $46,85 \pm 0,58$ \\
\hline
\end{tabular}

Jumlah ligan sangat menentukan besar efisiensi penandaan. Dengan jumlah ligan yang tidak memadai akan diperoleh efisiensi penandaan yang rendah karena meningkatnya jumlah pengotor yang dihasilkan. Berdasarkan hasil percobaan diperoleh data bahwa jumlah ligan a-mangostin yang optimum untuk penandaan adalah $1000 \mu \mathrm{g}$ dengan kemurnian radiokimia 72,62 $\pm 1,31 \%$ (Tabel 2). Pada jumlah ligan dibawah dan diatas $1000 \mu \mathrm{g}$, kemurnian radiokimia menjadi semakin kecil. Hal ini disebabkan ikatan ligan dengan ${ }^{99 \mathrm{~m}} \mathrm{Tc}$ berada pada perbandingan mol yang optimal untuk menghasilkan kemurnian radiokimia yang tinggi. Jumlah a-mangostin dibawah dan diatas $1000 \mu \mathrm{g}$ dengan jumlah $\mathrm{SnCl}_{2}$ tetap menunjukkan penurunan hasil kemurnian radiokimia. Jumlah ligan dibawah $1000 \mu \mathrm{g}$ menunjukkan reaksi belum berjalan secara sempurna dikarenakan jumlah pengotor ${ }^{99 \mathrm{~m}} \mathrm{TcO}_{4}$ masih besar, sedangkan pada jumlah ligan diatas $1000 \mu \mathrm{g}$ menghasilkan penurunkan kemurnian radiokimia karena jumlah pengotor Tc-tereduksi $\left({ }^{99 \mathrm{~m}} \mathrm{TcO}_{2}\right)$ yang besar. 
Jumlah a-mangostin dibawah dan diatas $1000 \mu \mathrm{g}$ dengan jumlah $\mathrm{SnCl}_{2}$ tetap menunjukkan penurunan hasil kemurnian radiokimia. Jumlah ligan dibawah $1000 \mu \mathrm{g}$ menunjukkan reaksi belum berjalan secara sempurna dikarenakan jumlah pengotor ${ }^{99 m} \mathrm{TcO}_{4}$ masih besar, sedangkan pada jumlah ligan diatas $1000 \mu \mathrm{g}$ menghasilkan penurunkan kemurnian radiokimia karena jumlah pengotor Tc-tereduksi $\left({ }^{99 \mathrm{~m}} \mathrm{TcO}_{2}\right)$ yang besar.

Tabel 2. Hasil Penentuan Jumlah Optimum Ligan a-mangostin

\begin{tabular}{|c|c|c|c|}
\hline Jumlah $\alpha-$ & \multicolumn{3}{|c|}{ Kemurnian Radiokimia (\%) } \\
\hline $\begin{array}{l}\text { Mangosti } \\
\mathbf{n}\end{array}$ & ${ }^{99 \mathrm{~m}_{\mathrm{TcO}}}{ }_{4}^{-}$ & ${ }^{99 m} \mathrm{TcO}_{2}$ & $\begin{array}{l}{ }^{99 \mathrm{~m}} \mathrm{Tc}-\alpha- \\
\text { mangostin }\end{array}$ \\
\hline $250 \mu g$ & $\begin{array}{l}25,80 \pm 2,1 \\
3\end{array}$ & $15.63 \pm 0,85$ & $58,49 \pm 1,64$ \\
\hline $500 \mu g$ & $\begin{array}{l}15.31 \pm 1,3 \\
5\end{array}$ & $17,00 \pm 1,44$ & $69,07 \pm 0,59$ \\
\hline $750 \mu g$ & $9,7 \pm 1,98$ & $18,97 \pm 1,15$ & $71,33 \pm 1,05$ \\
\hline $1000 \mu g$ & $8,11 \pm 0,88$ & $19,46 \pm 0,93$ & $72,62 \pm 1,31$ \\
\hline $1250 \mu g$ & $9,49 \pm 0,92$ & $20,96 \pm 1,43$ & $69,55 \pm 1,00$ \\
\hline
\end{tabular}

Inkubasi merupakan langkah penting. Pada fase ini, reaksi kimia terjadi, menghasilkan pelabelan $99 \mathrm{mTc}$. Jika waktu inkubasi tidak memadai, reaksi pelabelan mungkin tidak selesai, dan produk radiofarmasi yang terbentuk mungkin memiliki kemurnian radiokimia yang rendah (14). Waktu inkubasi optimum pada suhu ruang diperoleh pada menit ke 0 dengan kemurnian radiokimia $86.5 \pm 1,31 \%$. Pada Tabel 1 , terlihat semakin lama waktu inkubasi menyebabkan penurunan kermurnian radiokimia hingga pada menit ke-60 persentase kemurnian radiokimia berkurang menjadi 70,4 $\pm 1,37 \%$. Untuk membandingkan pengaruh suhu terhadap waktu inkubasi, dilakukan juga percobaan pada suhu dingin.

Tabel 3. Hasil Penentuan Waktu Inkubasi Optimum pada Suhu Ruang

\begin{tabular}{|c|c|c|c|}
\hline \multirow{2}{*}{$\begin{array}{c}\text { Waktu Inkubasi } \\
\text { (menit) }\end{array}$} & \multicolumn{3}{|c|}{ Kemurnian Radiokimia (\%) } \\
\hline & ${ }^{99 \mathrm{~m} \mathrm{TcO}_{4}^{-}}$ & ${ }^{99 m} \mathrm{TcO}^{2}$ & ${ }^{99 \mathrm{~m}} \mathrm{Tc}-\alpha-\mathrm{man} g o$ stin \\
\hline 0 & $10.05 \pm 1,01$ & $3.44 \pm 0,48$ & $86.5 \pm 1,31$ \\
\hline 15 & $11,6 \pm 0,97$ & $7,27 \pm 0,74$ & $81,18 \pm 1,6$ \\
\hline 30 & $12,13 \pm 1,49$ & $9,68 \pm 1,21$ & $78,2 \pm 0,57$ \\
\hline 45 & $12,85 \pm 1,15$ & $14,94 \pm 1,33$ & $72,2 \pm 1,49$ \\
\hline 60 & $12,69 \pm 1,49$ & $16,9 \pm 0,67$ & $70,4 \pm 1,37$ \\
\hline
\end{tabular}

Berdasarkan hasil percobaan waktu inkubasi optimum pada suhu dingin juga diperoleh pada menit ke 0 dengan kemurnian radiokimia $85,23 \pm 0,9 \%$.

\section{Ucapan Terima Kasih}

Terima kasih kepada Kemenristekdikti yang telah mendukung penelitian ini melalui hibah PKM-PE 2019 dan kepada BATAN yang telah menyediakan tempat dan radioisotope untuk penelitian kami. 


\section{Kesimpulan}

Penandaan $\alpha$-mangostin dengan radionuklida ${ }^{99 m}$ Teknesium berhasil dilakukan dengan kemurnian radiokimia yang optimum sebesar $86.5 \pm 1,31 \%$ pada temperatur ruang dengan jumlah ligan a-mangostin sebesar $1000 \mu \mathrm{g}$, reduktor $\mathrm{SnCl}_{2} 50 \mu$, pada $\mathrm{pH} 9$ dengan waktu inkubasi 0 menit (tanpa waktu inkubasi). Kemurnian radiokimia yang dihasilkan belum memenuhi persyaratan yaitu lebih dari $90 \%$. Perlu dilakukan penelitian lebih lanjut dengan menggunakan reduktor atau metode yang lain untuk menghasilkan kemurnian radiokimia ${ }^{99 m} \mathrm{Tc}-\alpha-$ mangostin yang memenuhi persyaratan yaitu diatas $90 \%$.

\section{Daftar Pustaka}

1. Vieira, L.M., Kijjoa, A. 2005. Naturally-occurring xanthones: recent developments. Curr. Med. Chem. 12:2413-2446.

2. Peres, V., Nagem, T.J., Faustino de Oliveira, F. 2000. Tetraoxygenated naturally occurring xantones. Phytochemistry. 55: 683-710.

3. Shan, T., Ma, Q., Guo, K., Liu, J., Li, W., Wang, F. 2011. Xanthones from mangosteen extracts as natural chemopreventive agents: potential anticancer drugs. Curr. Mol. Med. 11:666-677.

4. Peterson, Kent D and Terrence E. Deal. 2009. The Shaping School Culture Field Book. Second Edition. San Francisco: Jossey-Bass.

5. Yates, P., Stout, G.H.. 1958 . The structure of mangostin. J. Am. Chem. Soc. 80:1691-1700.

6. Matsumoto, K., Akao,Y., Kobayashi, E., Ohguchi, K., Ito, T.,Tanaka, T., linuma, M. and Nozawa, Y. 2003. Induction of apoptosis by xanthones from mangosteen in human leukemia cell lines. J.Nat. Prod. $\underline{66}: 1124-1127$.

7. Nabandith, V., Suzui, M., Morioka, T., Kaneshiro, T., Kinjo, T., Matsumoto, K., Akao, Y., linuma, M. and Yoshimi, N. 2004. Inhibitory effects of crude alpha-mangostin, a xanthone derivative, on two different categorie of colon preneoplastic lesions induced by 1, 2-dimethylhydrazine in the rat. Asian Pac. J. Cancer Prev. ㅁ: 433-438.

8. Y.Akao, Yoshihito Nakagawa, Munekazu linuma and Yoshinori Nozawa. 2008.AntiCancer Effects of Xanthones from Pericarps of Mangosteen .Int. J. Mol. Sci. 9:355-370.

9. Shibata, Yoshinobu Matoba, Hideki Tosa and Munekazu linuma. 2013. Effects of Mangosteen Pericarp Extracts Against Mammary Cancer. Altern Integ Med. 2: 139.

10. Muchtaridi. 2014. Dasar-dasar radiofarmasi. Yogyakarta: Deepublish.

11. Moadel. 2011. Breast cancer imaging devices. Nuclear medicine J. 41(3): 229-41. 
12 Choi C.W., Lee D.S., Chung J.K., Lee M.C., Kim N.K., Choi K.W., Koh C.S. 2001. Evaluation of bone metastases by Tc-99m MDP imaging in patients with stomach cancer. Clin Nucl Med. 20(4):310-4.

13. Sheth SG, Amarapurkar DN, Chopra KB, Mehta PJ. 2010. Significance of radioisotope bone marrow uptake on $99 \mathrm{~m}$ technetium sulphocolloid scan in portal hypertension. J Assoc Physicians India.44:310-2.

14. Lund, Walter. 1994. Pharmaceutical Codex. London : The Pharmaceutical Press.

15. Zolle, I. 2007. Technetium-99m pharmaceuticals. Berlin : Springer. 